\title{
The Humanistic Ideal City: Considerations on the Evolution of Patterns from 1422 to Late 16th Century
}

\author{
Andrea Spiriti ${ }^{1, *}$ \\ ${ }^{1}$ Department of Human Science, Innovation and Territory, University of Insubria, Como-Varese, Italy \\ *Corresponding author. Email: andrea.spiriti@ uninsubria.it
}

\begin{abstract}
The two big centers of the humanistic towns of Castiglione Olona (from 1421) and of Pienza (from 1462) clear the way for a phenomenon which in the middle of 16th century founds its coding in Sabbioneta (from 1554). There are many various ideal cities which travel along the century and often suggest methodological questions: ideal cities or simple high quality projects on an architectural and urban scale? Innovative districts or real urban inventions? The paper proposes both a chronological and typological seriation and an enounciation of methodological criteria for the identification and the highlighting of the peculiarities proper of this chronological phase, partially different from what achieved in the second half of the 16th century.
\end{abstract}

Keywords: Ideal city, Renaissance, Italy, 15th Century, 16th Century.

\section{INTRODUCTION: THE ORIGINS}

The rich and articulated critical reflection of the last decades on topics related to the ideal city [1] produced an almost paradoxical, but not unpredictable sentence: that is to complicate the issue by superimposing total or partial urban plans, urban interventions in previous context, figurative or literary idealizations, that means realities which share certainly tangence's and connections, but that can't ben superimposed automatically. At the origin there is the variation itself of the semantic application, which ranges from the simple acknowledgement where the urban and building practice is inspired by utopian motifs or even ideal to the more severe verification of the concomitance of many factors, both spatial and social historical. There is no doubt that in humanism coexists the privileged link with classical word (which, not certainly right it is the predictable thematic prototype), the utopistic impulse and the anthropocentric approach which represent other valuable joint to understand the phenomenon. Thus the humanistic ideal city along the almost two centuries long time- the XVth and XVIth century seems the perfect benchtest of verification.

A first, maybe obvious consideration about the humanistic sources is that defined with the fascinating expression the "denied antiquity" [2], [3]: the fact that the Italian 15th century can come to terms with the well handled Latin patterns (especially the imperial ones) and the Greek patterns gradually rediscovered (just see Ciriaco de' Pizzicolli's [4], [5] Turkish travels where he could visit the big Hellenistic towns and sites); but it basically ignores the Near Eastern [6], from the Mesopotamian urbanism (and the Pakistani reverberation) with the dialogue between the temple and palace, to the Syrian and Hittite city-states and the capital cities (from Ebla to Mari, from Hattusa to Karkemish), as well as the utopian gigantism of the Egyptian temple-cities (see the Theban areas in its different variations) and the capital cities founded ex-novo from Aketaton a Tanis/Per-Ramses where the absence of pre-existing traces better allows the fully unfold of the primacy of the symbolic scale. I don't refer, obviously to the pragmatist functionalism of the working-class cities, from el-Lahun forward. The Humanism lacks of this all as well as the almost hectic sequence of the Assyrian royal capitals and the following Persian codification culminating in the palatial utopia of Persepolis. It remained only the ambiguous myth of the Babel Tower, the microcosm which fails trying to alter the equilibrium of the cosmos: and the myth is as well long-lasting as of multiple and varied meanings. 
The 15th century focus is addressed to the GreekRoman world, starting from the living and ambiguous theme of the geometrical inspiration, which wrongly is considered properly of the ideal city. Of course, the Archaic Greek colonization often applied to the new urban foundation and to the surrounding territories a subdivided praxis of geometric origin and orthogonal prevalence which is really valuable to practical purposes and clearly noticeable in sites as Selinunte and Himera or - considering a more ambitious urban scale and thus with concessions - Agrigento or Siracusa, going up the peninsula and influencing the Etruscan world in the fascinating case of Marzabotto. The problem is not just the use of the geometrical scheme, but the subtended or not equivalence between rational and geometry and especially the idea which this process was not a forcing of polymorphic nature, but the rediscovery of deep geometric roots of the nature itself. Considering this all it seems unquestionable Pythagoras' role in Samo (580/570-495 BC) [7], partially reflexed in the same Crotone urbanism; and Pythagoras is unread author (for obvious reasons of non-philological subsistence and for the nature itself of his teaching) but quoted and really present in the collective imagery until Modernity. So, the urban geometry considered as the rediscovery of an order, as correlation with the anthropic microcosm to the heavenly macrocosm. It seems logical, considering a more and more ideologic rarefaction, to read this position as an introduction to Plato, but it is not totally correct. The Athenensian philosopher (428/427 - 348/347 BC) [8] could just share the mathematical mysticism - ageométros medéis eisíto was written on the door the Académeia -and the whole plan of the Politéia (380/370 ca.) got almost necessary a physical translation which Plato does not propose. But in the Nómoi (350 ca.) is clear the position against the excessive orthogonal geometries, considered unaesthetic. The rule, but also the living exception, in subtle analogy with the same eponymous laws. We have to consider that this is not Inside a Greek world which as well could see the recent great building project - geometric until it became eponymous by Hippodamus (498-408 BC ca.) [10] for his Miletus refounded after the Persian Wars; as well as the shortly thereafter cases of Pella and Priene, but also of Sibari/ hurii. It has not to seem a paradox, but the philosophic utopia proposes less rigid schemes than the town planning practice. The situation is different and herald of strong humanistic consequences, for the Hellenistic world: the model of Alexander the Great, founder eponymous from 332/331 BC. Of even thirteen Alexandrias, shortly imitated with numerous eponymous and paronym towns (Philadelphia, Apamea, Antioch, Ptolemais,
Seleucia...). Considering these assumptions, the Hellenization already accomplished in the Roman society of hand II century BC could just applied with increasing rigor those paradigms, both in the colonies and both in the great urbanization plans, during the imperial age especially, to get up to the remarkable case of the refoundation of Byzantium as Néa Róme/Costantinople in $330 \mathrm{BC}$, whose impressive dimensions would be a steady implication until 15 th century. As a sideline, there is the overlap of the Christian Jerusalem to the Jewish and the Roman ones, also considering the immediate premises of Hadrian's dystopian since 135: with the places of Jesus' earthly presence which give a sacred and utopian values (see the role of the Anástasis). In turn, this was relaunched in theological terms by the celestial and terrestrial semantic wealth of the Sacred town in De civitate Dei by Augustine (413-426); and islamism would complete the picture from 638 with its holy places.

This formidable classical heritage is -as always happens to Humanism - filtered, despite the protests, through a Medieval Age denied as much as metabolized. Between 9th and 12th century, the urban or peri urban refoundations, after the 5th-8th century crisis, are based on two fundamental lines: the revival of the palace-capital city scheme, remarkable in the Carolingian Aachen [11], and the innovative one of the monastery-city, displayed by the Sankt Gallen parchment [12], but obviously more widespread. In both cases, in the light of Saint Augustine, the innovative theme is the sacral one which introduces a strong utopian streak, even in the singularity of urban spaces intended for particular communities: on one side the court and on the other the monastic family. In this way, the Church and the Empire (often with less strains in the Reich territories) are the designated protagonists, as the 12th century events demonstrate considering the war among Frederick I against Alexander III and the Lombard League [13], [14]. In 1158 Laus Pompeia (today Lodi Vecchio) was completely destroyed by the Milanese; in the same year the town was refunded by Frederick I as Laus Nova (today Lodi) with a partially regular plan. In 1159 the Kaiser destroyed Crema and in 1162 was the turn of Milan [15]; in 1167 the metropolis was rebuilt, with a crucial formal transition, by archbishop Galdino and the municipal institutions [16], [17]. In 1168 the League founded Civitas Nova, later Alessandria, in eponymous hour of pope Alexander III; during the Peace of Costance of 1183 the Emperor authorized the reconstruction of Crema (as castrum!) And refunded Alessandria under the name of Cesarea (and quickly after returned to the 
previous name). The obvious hiatus between formal acts and concrete actions doesn't appeased the evident strength of the legal data, with the Milanese tear reasoned by the strength of Ambrosian episcopal tradition.

Compared to such authoritative paradigms, are less decisive the numerous "colonial" towns in Italy and Europe between 13th and 14th centuries founded for defensive needs and for territorial control as well as for redemptive will of agricultural areas (the so called Terranuove) as for post-seismic reconstructions: all too idealized cases as Montereggioni are interested but not to be emphasized. Different is the situation of Cagli. The old Piceno town was almost all destroyed in 1287 by a fire hanged by the Ghibelline faction; the Guelph fugitives had taken refuge in the (re) founded Sassoferrato. Pope Niccolò IV Masci (1288-1292) promoted the reconstruction of Cagli in the NorhEast side of the previous inhabited areas, with a orthogonal mesh plan attributed to Arnolfo di Cambio [18]. Its urban restocking is documented by 1312 taxation. Even in the absence of many comparisons now modified, it's clear the confluence of two strands: the Frederick classicist utopianism (possibly it was like this Foggia the capital town created ex nihilo!) mediated to Arnolfo through Nicola from Bari/ Pisa (Nicola Poisano) and the great patronage by the first Franciscan pope with the famous, astonishing, commissions of Rome and Assisi. One element is not trivial: to the dissolution of the urban space which is also the collapse of the common life takes the place a refounding gesture which, as it was made by the pope, cancelled the vulnus and restored sacredly the civitas: the Alessandria pattern in a more radical version. A particular case, as a true microcosm, is that of the Duomo Nuovo of Siena [19]: the colossal undertaking, already doomed to failure because of the urban impact of the utopian giantism, and yet carried out from 1339 to 1357.

\section{THE FIRST IDEAL CITY: CASTIGLIONE OLONA}

These are the premises (a little bit different compared to the historiographical vulgate) for the humanist reworking of the theme of the ideal city, whose impact can be clearly seen in the first astonishing case in Italy: Castiglione Olona ("Figure 1") [20].

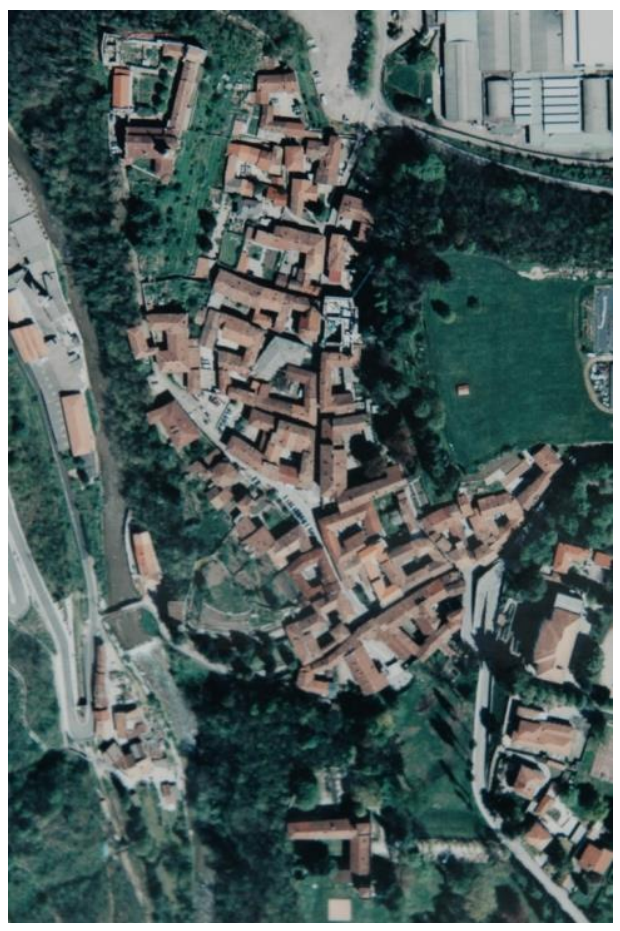

Figure 1 Castiglione Olona, Italy.

From $1421 / 1422$ to 1443 cardinal Branda Castiglioni (1357/1358 - 1443), political and religious leading figure during the age of the Western schism, of the Hussite heresy, of the reunification with the Orthodox during the Florence Council (1439) converted a little Medieval village, eponymous of his family, in the first ideal city of Humanism. My recent book on the subject exempts me from a thorough analysis. I repeat the characterizing data:

- The dialectic between the Villa (the city centre) and Rocca (seat of the Collegiate church) allows an interpretation following Augustian terms, that is the dialectic between Civitas hominum and civitas Dei.

- The barycentre of the Villa is a triangular place from which three road axes depart with a clear Trinitarian allusion.

- The city is placed on a morainic strip, dominating the river Olona, between the two hills of the fortress and Monteruzzo castle: all data easily interpretable in symbolic terms.

- The nature is presente in the village (the Branda palace garden, the climb to the fortress along the slope), but artate and rationalized by man; it is totally different from the forest once surrounding, place of wild animals (and infact a hunting 
destination) and so allusive of barbaritas opposed to civitas hominum.

- The deep ekistic value the foundation is remembered on a fireplace in the Branda palace where the first Lombard epigraphic inscription in Greek language evokes the foundation and the prosperity, retrieving the schema fire/ fireplace/ room/ palace/ city whose great classic pattern is the domus Vestae in the Roman forum.

- The messianic connotations (the systemic presence of the Palma dactilifera) confer an eschatological and parenetic thrust.

- The classical world (Relative's palace portal, Baptistry frescoes) is considered as deeply connected with the Christian one, according to the protreptic interpretation introduced by Eusebius of Caesarea and Basilius the Great: and this is deeply humanistic.

- Many services (forum, school, sacred places) are blatantly oversized compared to the demographic needs: that is to show the social world has it would be, and not as it is, and utopianism is playing on this.

- The Scolastica building, current town hall, is especially remarkable as it is the most ancient humanistic scholastic building in Europe (the $\mathrm{Ca}$ ' Zoiosa of Guarino and Vittorino in Mantova and Ferrara was part of the princely palace, not an autonomous building). It was built as an emerging block with wide rooms and a hanging garden, following the logic of total education and of dulcedo discendi which qualifies Guarino's and Erasmus' humanistic pedagogy in strong controversy with the medieval violent and coercitive education, but also with the classical one, let's consider the plagosus Orbilius by Horace.

- The project marked a turning point in 1439 , which determined even a partial destruction of the frescoes just painted and which implied variations as the grave-grill of the cardinal in the Collegiate church and the symbolic and trinitarian oculus windows introduced in the same religious building and in the Villa church.

- This last building is a sort of tabernacle church of Body of Christ, filled of references to the Byzantine world just reunified: it is obvious the influence of Branda's great scholar friends, as Niccolò from Cusa (for the perfection of the circumference) and Basilius Bessarione (former Orthodox cardinal).
- A parallel utopianism, this time expressed through painting, can be fine in the double figuration (Collegiate church and Baptistery) of the project (1435/1438) to reconstruct the Vatican Saint Peters basilica as a central domed plan building which, on one side, supports the references to the Byzantine world, on the other, anticipates by seventy years the project commissione by pope Julius II to Bramante.

- It is finally giving up the use of the improper 'label' of "Tuscan island in Lombardy" to explain Branda's will to create a microcosm which synthesizes (and in this it is really "ideal") the continental macrocosm, in concrete terms calling Italian artists (Lombard, and especially from the Lombard and Tessin Lakes area in touch with the Venetian and Friulian areas; Florentine and Sienese ones) and European masters (Bohemians, Germans, Flemings, French and British) to create the concordia discors so loved to Cusano; with the leading presences of Masolino from Panicale, Paolo Schiavo, the Vecchietta, and the Solari family from Carona.

However, characterized by a dynastic identitary dimension (Branda's nephews both lay and ecclesiastical are widely present in the decorative cycles), Castiglione Olona is first of all the Augustinian and humanistic project: a sacred structuring which reflects itself on the whole city and determines the connection between symbolic caliber and architectural strategies. This is a pattern which, on a minor scale, can be found in different other cases: I just mention that of Finalborgo [21], rebuilt from 1450 after the destructions of 1447-1449.

\section{THE SECOND HALF OF XVTH CENTRURY}

The same method features implemented in Castiglione can be find in the second ideal city of Humanism: Pienza [22], [23]. In February $1459^{1}$ pope Pius II Piccolomini visited the village of Corsignano ("Figure 2"), where he was born in 1405, and decided for a urban transformation, directed by Bernardo Rossellino, interrupted after the pope's death in 1464.

1. For the pope's visits and his patronage his Commentaria are irreplaceable: I quote from [24]: libro II, n. 20, pp. 312-315; libro IV, nn. 34-35, pp. 782-789; libro VIII, n. 5, pp. 1576-1581; libro IX, nn. 23-26, pp. 1745-1777; libro X, nn. 19-20, pp. 1941-1951. 


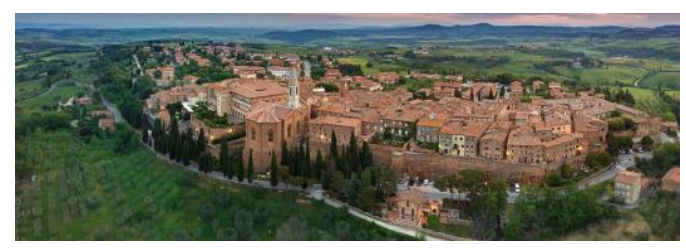

Figure 2 Pienza (former Corsignano), Italy.

The two different deeds of incorporation were the change of the village name with the onomastic one of Pienza (an option, we can say of hellenistic taste) and the institution on 13 August 1462 fo the diocese (the prot-obishop Giovanni Cinughi took office on 1 September). The urban plan is that of a rectangular figure with rounded corners, with axial decumanus, today Rossellino street, and a barycentre as a forum (today Pio II place) with the cathedral, Piccolomini palace, formerly cardinal palaces and the one of the canons. The only urban significant survival, on the West side of the dynastic headquarters is the Medieval convent of Saint Francis; and the extraurban parish church of Saint Vito, connected actually to the baptism of future pope Pius II. The sacred value is evidente in the overhang positioning of the cathedral apse, with all the references to the City of God on the Mountain, but also of Oreb/Tabor/Golgotha and of pinnacle of the Temple.

One different element from Castiglione is the patrons' rank: in Lombardy a cardinal who was the exclusive dominus; in Tuscany one pope who planned a repurposing of the cardinal court on a minor scale with the different palaces place side by side the papal one. One other element is loxodromic: Pienza is flat, but on the South side overhanging, thus gaining the two values of the regular structure and of the dramatic precipice. Nor should the classicist instance be underestimated: Enea Silvio Piccolomini was well aware of his Roman Trojan onomastic; and the departure from Corsignano/ Ilium determined the foundation of Pienza, the new Lavinium/Albalonga/Rome, which, moreover, ends up reconnecting to the universal episcopal seat of the pope. Even in Pienza the green areas have a precise role, but included in the rationality of the palace gardens. if anything, the visual impact is wanted towards the plain, with a scenography which can be fine in Urbino and which implies the domination of human rationality on the shining natural landscape.

Considering the ideal, humanistic and sacralizing premises, it is difficult to place evenly the numerous subsequent urban manifestations. A first trend is certainly that of the treatise, started around 1464 with the famous Filarete's project of Sforzinda [25, 26]. If the onomastic choice, the geometric, but not rigid pattern, the accentuated astronomical value can constitute as many stages to the secularization of the pattern, what is missing is the implementation, remaining the abyss unbridgeable - without prejudice to the stimulating value of utopia - between the graphic display which basically can afford everything (and it will last for centuries) and the implementation of a cost, technical difficulties and even social accessibility based practice. During the age of Federico da Montefeltro (in fact, from 1464 with the presence of Luciano Laurana) [27]. Urbino could even count on the "palace in the form of a city" (hence microcosm of microcosm), the plateau with visual impact on the plan, the discreet but constant rationalization of urban space, the prevailing innovative tone, but it is not a proper ideal city. It is a splendid humanistic palace with a functional city. And the same for the famous late 15th century views by fra' Carnevale [28], [29], which are a little bit disturbing with their icy perfection and lacking a true urban vision: it is a limit between theatrical scene and abstraction, more similar in anything to treatises.

We need to get to the foundation of Giulianova [30], [31] to find something different ("Figure 3").

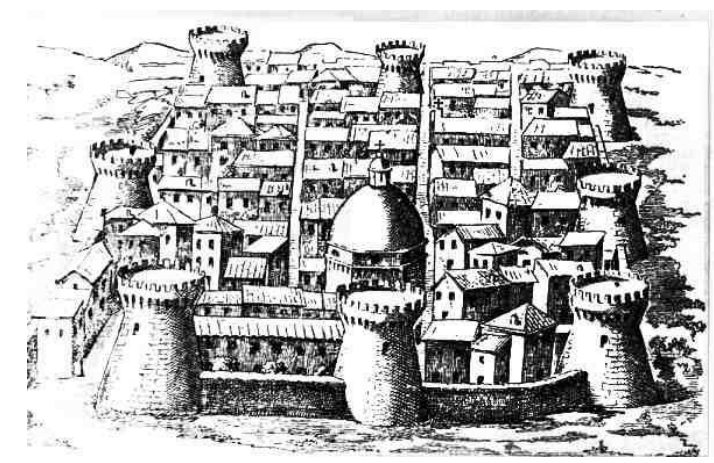

Figure 3 Giulianova, Italy, etching, 16th c.

In 1460 Castel San Flaviano in Abruzzi it had been depopulated by the homonymous battle; in 1471 Giulio Antonio Acquaviva (1428-1481) refunded the city with its own eponymy. Some data must be collected: the future kinship with the Piccolomini dynasty $^{2}$ the detachment of worldliness suffered by the Church during the papacy of Sistus IV Della Rovere (1471-1484); the foundation in the Kingdom of Naples, which implied the logic of feudal foundations and of baronial control of the land that was different from the political setting of the NorthCenter of Italy. In fact, I think Giulianova represents the beginning of the second phase of the Italian ideal

2. In 1477 Andrea Matteo, heir of Giulio, married Isabella, daughter of Antonio Tedeschini Piccolomini, who was the son of Pius II's and Pius III's brother. 
city, even more connected to the fiefdom than to the princedom (and we discuss about it), but now less tied to sacralizing logic as Castiglione Olona and Pienza. Of course, even in this case, there is the bond with the East: the Saint Flaviano relics, patriarch of Constantinople from 446 to 440 and martyr; and the cathedral of Santa Maria di Piazza with its central domed plan. But the orthogonal implant, the emphatic role of a now noble mansion now (or at least feudal) which is no more the domus belonged to the Castiglioni or the Piccolomini, and the deep connection with the turreted wall structure (while the walls are symbolic in Castiglione and Pienza) are new data.

One step is still missing: that from fief to princedom, how at least the second term takes shape in the debate $\mathrm{e}$ and in the political praxis of the second half of the 15th century. Considering these themes the earlier cases are Cortemaggiore [32] ("Figure 4") and Carpi.

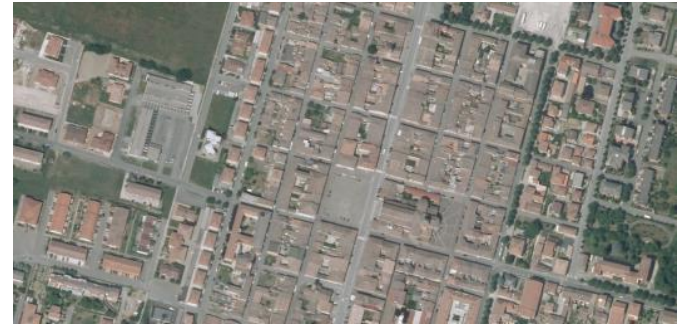

Figure 4 Cortemaggiore, Italy.

In the first case, the capital town of the Pallavicino's small but vital state was qualified starting from the foundation by Giovanni Ludovico in 1479. If the second half of the 15th century appears particularly qualified by ecclesiastical foundations, starting from that of the collegiate church of Santa Maria delle Grazie (from 1480) and of the church of the Annunciata with the convent of the Franciscan Observance (from 1489, in early 15 th century a orthogonal plan was brought to completion, with classical axis, low facades, arcades, wide and airy avenues: a well calculated equilibrium between geometrizing instances deriving from Leon Battista Alberti's lesson and the social attention to the livability criterion -typical of the ideal city. In 1336 the Este dynasty feuded of Carpi [33, 34] the Pio family, since 1450 Pio di Savoia for the military merits acquired from the dukes; the family domain lasted until 1531. At Lionello I's death in 1480 the fief remained in the hands of his brothers Gilberto II (who in 1499 opted for the lordship of Sassuolo) and Marco II, who was succeeded by his son Lionello II in 1490. But since 1480 the lordship was shared with Lionello I's son, Alberto III, from 1519 Sarsina count. Basically, a series of family conflicts from 1494 to 1509 determined Alberto's primacy who for twenty-five years had already promoted urban renewal of the village, lasted until his exile in 1525 . Giovanni Pico della Mirandola's nephew, pupil of Aldo Manuzio, Alberto is a man of strong humanistic interests which are reflected in the urban transformation, directed by Baldassarre Peruzzi; and already this use of the great Sienese-Roman architect is significant. The emerging elements ("Figure 5") are the palace-castle (that is, the skillful coexistence of the low medieval military structure with the courtly transformation), the arcades (a classic sign of urban sociability), the walls demolished today, the cathedral of Santa Maria Assunta (archpriesthood extradiocesan at least from 1113, Carpi became formally diocesan seat in 1779), the parish church of Santa Maria in Castello (la Sagra), the church of San Bernardino da Siena and the convento of the delle Poor Clares ${ }^{3}$ and generally a dense presence of ecclesiastical foundations. But the most important element is the courtly value: emerged from a complex "Merovingian style" family domain, Carpi was qualified by Alberto III in the knowledge that in the climate of mature humanism, only consistent patronage operations can justify a fragile power. The logic not understood by the tyrants of Romagna, the historical or the new ones (Gerolamo Riario, Cesare Borgia), instead transforms the Carpi dispute into an ideal city, rationalized but livable, symbolic but concrete.

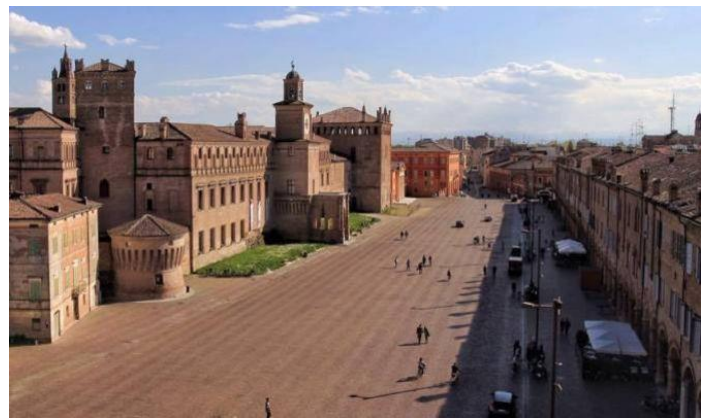

Figure 5 Carpi, Italy.

There is much to reflect on this urban mirroring of the humanistic lordship, on this cultural justification of the princedom, which is thing long gone form the sacralized ideal city. To some extent, this can be true for all courts, from the great capital city to little centers; and they all contain some idealizing element or some more ambitious intervention. Thus, Gerolamo Riario's domain non

3. Remember the presence of Camilla Pio, cousin of Alberto III and locally venerated as blessed. 
Imola (1473-1488) and Forlì (1480-1488) and continuation of the regent widow Caterina Sforza (1488-1499/1500) certainly determined an urban rationalization, a powerful wall system, the large fortresses, and were exalted and idealized in retrospect by the famous 1502 drawing by Leonardo da Vinci [35]. But the weakness of the overall project contributed to the fragility of the Riario-Sforza domain. Thus the Additio Herculea [36] built in Ferrara from 1492 under the direction of Biagio Rossetti and Gabriele Frisoni from Laino (it is worth highlighting the role of this great Lombard Lake architect, often and wrongly limited in the role of mere performer of Rossetti) is certainly an extraordinary example of urban planning of a large expansive area, but it can't be defined as an ideal city. Thus the ducal place of Vigevano (1493/1495) [37] is certainly ingenious in repurposing the forumpattern with the continuous portico which connects the castle and the future cathedral, creating an early "scene of the prince" whose entrances, anyway, make you understand the different nature compared to the urban space of which it also constitutes the barycentre: but for this very reason it is not an ideal city.

The Italian crisis from 1494 certainly caused a prolonged stasis, so that in the first half of the sixteenth century there are few useful cases in general new feudal foundations within the limits described above. A borderline case because it is a direct emanation of the ruling house is Ferrandina [38], [39], the ancient Uggiano Lucana ("Figure 6").

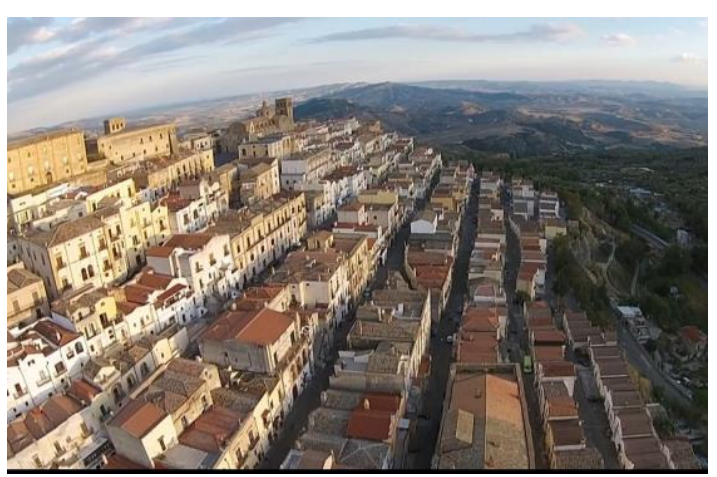

Figure 6 Ferrandina, Italy.

King Federico performs this onomastic act in 1496 (and not in 1494!), in honor of his father Ferrante and in the logic of the reinstauratio of the Aragonese monarchy after the crisis of 1495. The result - though incomplete and not by chance, in the logic of legitimation, resumed in 1507 by the cousin and heir Ferdinand the Catholic - can be considered an ideal city, with a dense presence of sacred foundations, especially conventuals, in dialectic with a strong agricultural activity and of wool production; and an original urban plan with parallel streets with the use of terraces. A particular speech deserves Acaya [40], [39], hamlet of Vernole in Salento ("Figure 7").

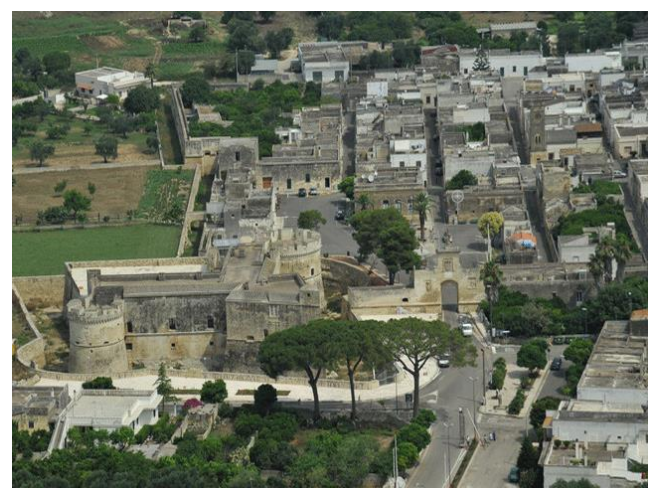

Figure 7 Acaya, Italy.

The Segine village was in fief to the Acaya in 1294, transmitted in 1535 to Gian Giacomo (1500 ca. - 1570) who immediately gave his name to his native village and started an ambitious project of transformation, strong of his own competence of royal military engineer which materialized in a dense activity through the whole Kingdom of Naple.

The foundational inscription is exemplary for the serial sequence: "moenibus cinxit, instauravit, publicis privatisque aedifitiis decoravit, et Achayam ex suo cognomine appellavit"/ the erection of the walls (sacred act, let's think of Romulus), the formal foundation, the public and private decor, the renaming. Of course, the architect-prince creates a singular situation compared to the feudal foundations of the South. And it is interesting for this linking up with the alleged pagus founded by the ancestors, a deviant but notable reminder of the Greek colonization and of the Roman municipalization. Unfortunately, the village was devastated by the barbarian pirates in 1714 , but the impressive and updated fortress-palace still remains in the SouthWest side, the quadrangular walled structure with corner bastions and, quite well preserved, the orthogonal grid of insulae in ratio 1:4 (compared to 1: 3 considered by Hippodamus of Miletus). It is also remarkable the places system, the major one in front of the castle (the 15th century plan of Castel Sismondo in Rimini), the minor one in front of the parish church of Santa Maria della Neve. 


\section{NEW AND ANCIENT: THE CINQUECENTO}

The objective datum is however the welding, only for the 16th century, between the geometric rigor of the system and the urban ideality rate, also found in urban planning of the new capital towns (emblematic the case of Torino from 1563, but let's think also to the uninterrupted urban planning effort of Rome during the whole 16th century) which can't be considered - I repeat -ideal cities, but continuations of the open topic with Ferrara. The same goes for military citadels, with urban plan functional to the defensive structure and often refined updates with respect to the evolution of military technology: but the result is a strict geometric structure, not an ideal city for the same functional definition underlying. And this can be applied for Terra del Sole (dal 1564) as well as for many other Italian and European cases. It is certainly an ideal city Sabbioneta [41], projected since 1554 and built from 1556 for the will of his duke, Vespasiano Gonzaga Colonna (1531-1591), at whose death the project was substantially concluded ("Figure 8").

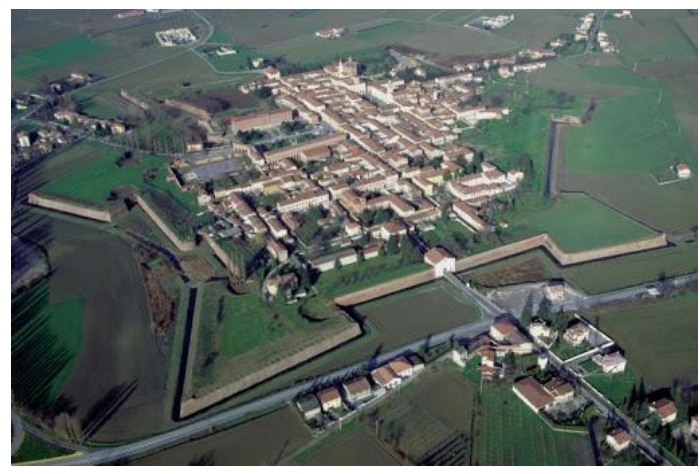

Figure 8 Sabbionetta, Italy.

The creation of the town and the duchy inside the "Gonzaga galaxy", they had been conserved, demonstrating as much as the "prince scenery" was Sabbioneta; indeed, taking it to the extreme, it can be considered a semantic pivot the Olympic Theatre which, in parallel to the Vicenza one, was released in 1588 by the Lake Artist Vincenzo Scamozzi from Valsolda. A very incomplete premise is Guastalla, from 1541 fiefdom of Ferrante Gonzaga and with the topical element of the monument to the ecyst, work by the Lombard Lake artist Leone Leoni, in the major place.

The first identifying datum is the grandiose regularity of the wall circuit with a pentagonal bastion plant, whose internal surface is higher than the urbanized area, following the same "surplus" pattern already seen in Castiglione Olona. Then there is the articulation of the princely spaces (the Ducal Palace, Ancients Gallery, Garden Palace and the already mentioned Theatre), together inserted and autonomous from the urban space, following the logic of the Florence of Cosimo I de Medici; and the particular importance of the sacred buildings (parish church of Santa Maria Assunta, temple of Santa Maria Incoronata) with a strong Mariological connotation and the emphasis, in the second case, of the funeral monument of Vespasiano, but also the urban marginalization and the close dependence from the ducal Palace.

The point of suture between military city and ideal city is established by the foundation of La Valletta ("Figure 9") in Xagh-ret Meuuia on the Malta Island [42].

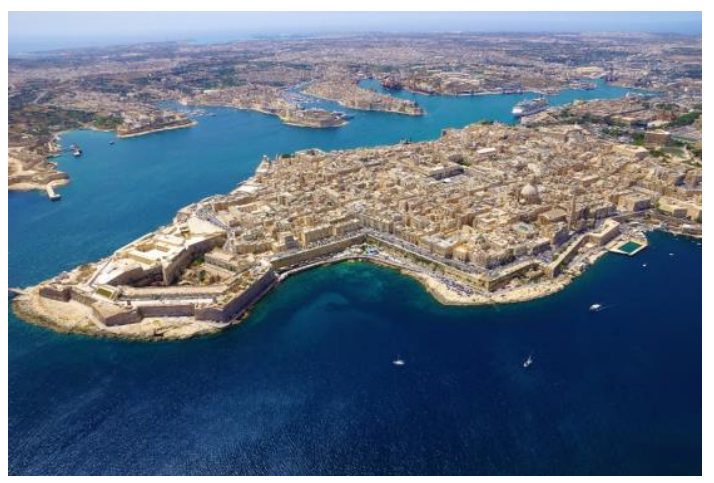

Figure 9 La Valletta, Malta.

After the Turkish siege, on 28 March 1566, the Grand Master of the Order of Malta, Jean "Parisot" del La Valette, made use of the great architect, Francesco Laparelli, sent by pope Pius IV Medici to project what is both a new capital, a mighty fortification and an ideal city, strongly symbolic as an anti-Turkish anthemural of Christianity and not by chanced named Città Umilissima. The ideological instance becomes concrete in the link between the defensive structure and the orthogonal plan city which favors the partitioning into neighborhood polarized on religious foundations or ethnic nucleus. Sacred city in a unique way, therefore direct heir of the fifteenth-century paradigms, and inhabited primarily by the parádoxos politéia of monkswarriors from the vocational and not genetic exchange, La Valletta is a sensational and unique case within the genre.

A direct derivate of Sabbioneta is instead the Doria fiefdom of Loano ("Figure 10") in the Ligurian Riviera di Ponente [43]. 


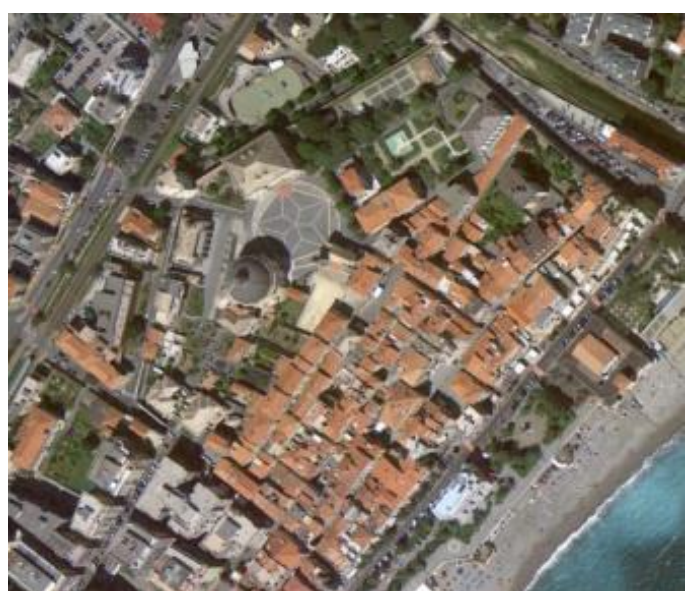

Figure $10 \quad$ Loano, Italy.

Here the patronage of Giovanni Andrea Doria with Zenobia Del Carretto and of Andrea II Doria with Giovanna Colonna created an ideal space, since 1575 and until the early decades of the 17 th century: a walled city (moreover with singular alternations, from powerful bastions to refined loggias) with a pentagonal plant, with orthogonal road system, three regular places, a dense presence of religious buildings - the cathedral, the ancient parish church, the Bianchi oratory inside the walls; the Loreto sanctuary and the three great Augustinian, Carmelite and Capuchin convents outside the walls - definitely excessive for public needs, but not for the symbolic ones. If in particular the complex of Sant'Agostino is linked to the first couple, the one of Monte Carmelo is the funeral space of the second couple, with all the visual instances of the now ancient dialectic seen in Castiglione Olona and the civitas hominum at the foot of the civitas Dei super montem posita and moreover emphasized by the large connecting viaducts. In Loano the reading of historical precedents is particular. The identification of the ancient village with the Roman Pollupice is entirely hypothetical, despite the mosaic findings, and the orthogonal scheme is totally ex novo; but it is also the return in 1309 to the Marina, for Raffaele Doria's will pact, of the medieval village super podium, that is near the future Carmelite convent.

At the end of the 16th century a point of synthesis and evolution is represented by the city fortress of Palmanova ("Figure 11") [44], founded in 1593 by the Venetian Republic (note: the only case of a republican state and not governed by an ecclesiastic or a prince) with an anti-Turkish and de facto antiHapsburg function, with the project of Giulio Savorgnan.

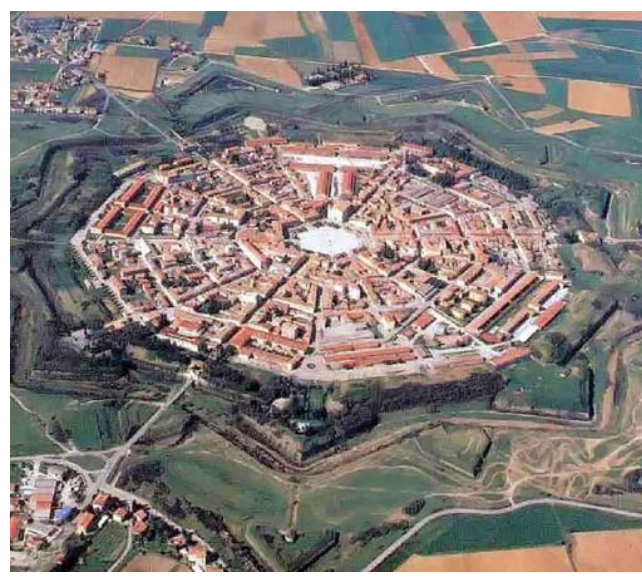

Figure 11 Palmanova, Italy.

What is striking is not only the polygonal star with nine points plan, but the correspondence of the wall structure with urban segments further divided and epicentered in the central hexagonal place, overlooked by the cathedral and the main civil institutions. The point is the convergence between an articulated and effective military structure; and urban space as well real, with a credible demographics and an idealized and emphasized logic of services and spaces. In this sense, the homologies with Terra del Sole and similar case are minor than the different logic: the fortress with living spaces is replaced by the city which is also a fortress. The accentuated geometric symbolism - not always consonant with properly military purposes -certainly responds to a classicist ideal which takes up the PythagoreanPlatonic model leading the way to a "geometric strip" of the Galilean Nature while depriving him of that astral correspondence important for the Renaissance and now impossible to propose in a counter-reformed context; but it is also an echo of the great classificatory age, that expressed in Venice by Giulio Camillo Delminio and Giordano Bruno in the Teatro della Memoria in parallel with the systemic evolution of maths after 1545, in the great age of Tartaglia, Ferrari and Cardano.

\section{CONCLUSION}

I consider a classification synthesis appropriate. If we attribute to the ideal city the unitary value of symbolic spatiality, social oversizing, more or less geometric structuring, we can see the relatively low number, eleven, of Italian humanistic and Renaissance cases, in parallel with a precise series of evolutionary stages: the sacred town (Castiglione Olona, Pienza), the princely/ feudal secular city (Giulianova, Carpi, Ferrandina, Acaya), its evolution even in the military field during the 16th century 
(Sabbioneta, La Valletta, Loano, Palmanova). A different matter Is that of the towns with ideal elements (starting with Finalborgo) or with ideal palace-spaces (Urbino) or district (Ferrara); or the parallel case of the military or strictly feudal foundations. Obviously a systematic comparison with the European cases can only help understanding the central Italian theme.

\section{AUTHOR'S CONTRIBUTIONS}

This paper is independently completed by Andrea Spiriti.

\section{ACKNOWLEDGMENTS}

Many thanks for the fruitful discussions to the scholars and friends of Ideal Cities of the Italian Renaissance.

\section{REFERENCES}

[1] H.W. Kruft, Städte in Utopia. Cities in Utopia. The ideal city from the 15th to the 18th century between state utopia and reality (Die Idealstadt vom 15. bis zum 18. Jahrundert zwischen Staatsutopie und Wirklichkeit), München, Beck, 1989 (In German).

[2] M. Liverani, C. Mora (eds.), The rights of the cuneiform world: Mesopotamia and adjacent regions, ca. 2500-500 BC (I diritti del mondo cuneiforme: Mesopotamia e regioni adiacenti, ca. 2500-500 a.C.), Pavia, Pavia University Press, 2008 (In Italian).

[3] M. Liverani, Imagining Babel: Two Centuries of Studies on the Ancient Eastern City (Immaginare Babele: due secoli di studi sulla città orientale antica), Rome-Bari, GLF Editori Laterza, 2013 (In Italian).

[4] G. Montanari, The Hero of Two Worlds: Politics, Archaeology and Passion for the Antique in the "Cultural Mediation" of Cyriac of Ancona between East and West, with a Note on the Birth of Venus by Botticelli, in M. Folini, A. Musarra (eds.), Cultures and Practices of Coexistence from he Thirtheenth through the Seventeenth Century. Multi-Ethnic Cities in the Mediterranean World, atti del convegno AISU, Genova 2018, Abingdon-on-Thames, Routledge, 2021, vol. I, pp. 165-186.

[5] G. Montanari, From Ciriaco to Sandro. Cultural and figurative models of Ancient Greece from
Pizzecolli's travels to Botticelli's paintings (Da Ciriaco a Sandro. Modelli culturali e figurativi dell'Antica Grecia dai viaggi del Pizzecolli ai dipinti di Botticelli), in "IKON", XIII, 2020, pp. 165-178 (In Italian).

[6] M. Liverani, Uruk - the first city (Uruk la prima città), Bari-Rome, GLF Editori Laterza, 1998 (In Italian).

[7] A. Mele, Pythagoras: philosopher and teacher of truth (Pitagora: filosofo e maestro di verità), Rome, Scienze e Lettere, 2013 (In Italian).

[8] F. Ferrari, Introduction to Plato (Introduzione a Platone), Bologna, Il Mulino, 2018 (In Italian).

[9] F. Trabattoni, Plato's philosophy: truth and human reason (La filosofia di Platone: verità e ragione umana), Roma, Carocci, 2020 (In Italian).

[10] P. Benvenuti Falciai, Hippodamus of Miletus architect and philosopher: a philological reconstruction of the personality (Ippodamo di Mileto architetto e filosofo: una ricostruzione filologica della personalità), Florence, University of Florence, 1982 (in Italian).

[11] B. Schneidmüller, (ed.), The emperors and the pillars of their power: from Charlemagne to Friedrich Barbarossa (Die Kaiser und die Säulen ihrer Macht: von Karl dem Großen bis Friedrich Barbarossa, exhibition catalogue), Mainz 20202021, Darmstadt, wbg Theiss, 2020 (In German).

[12] O. Reguin, Some measurements of the Plan of St. Gallen and of the Palatine Chapel (Aachen) examined in the metrological context (Quelques mesures du Plan de Saint-Gall et de la Chapelle palatine (Aachen) examinées dans les contexte métrologique), in: "Zeitschrift für schweizerische Archäologie und Kunstgeschichte", 77, 4, 2020, pp. 205-220 (In French).

[13] G. Barni, The fight against Barbarossa (La lotta contro il Barbarossa), in Storia di Milano, IV, Milano, Fondazione Treccani degli Alfieri, 1954, pp. 1-112 (In Italian).

[14] Milan and Lombardy in the communal age. XI XIII centuries (Milano e la Lombardia in età comunale. Secoli XI - XIII), exhibition catalogue, Milano, Silvana, 1993 (In Italian). 
[15] A. Spiriti - L. Facchin, Santa Maria Assunta al Vigentino, Milano, Silvana, 2012, pp. 13-15 and 17-22 (In Italian).

[16] M.T. Fiorio, "Opus turrium et portarum" the sculptures of Porta Romana ("Opus turrium et portarum": le sculture di Porta Romana), in: [14], pp. 189-192 (in Italian).

[17] G.A.Vergani. Records, in: Ancient Art Museum of Sforza Castle. Stone sculpture (Museo d'arte antica del Castello Sforzesco. Scultura lapidea), vol. 1, Milano, Electa 2012, pp.195-206 (in Italian).

[18] M.M. Scoccianti, The "Strada Magna". Medieval town planning in the Marche (La "Strata Magna". Urbanistica medievale nelle Marche), Roma, Bonsignori, 2003 (in Italian).

[19] M.M. Scoccianti, Sant'Angelo papale - Cagli: a thirteenth-century foundation in the Pontifical March (Sant'Angelo papale - Cagli: una fondazione duecentesca nella Marca pontificia), in: S. Ricci, E. Guidoni (eds.), Medieval New Towns. San Giovanni Valdarno, Tuscany and Europe (Città nuove medievali. San Giovanni Valdarno, la Toscana e l'Europa), Roma, Bonsignori, 2008, pp. 69-79 (in Italian).

[20] R. Bartalini, The new cathedral of Siena: the factory, the sculptures, the masters, the dynamics of the construction site (Il duomo nuovo di Siena: la fabbrica, le sculture, i maestri, le dinamiche di cantiere), Cinisello Balsamo, Silvana Editoriale, 2019 (in Italian).

[21] A. Spiriti, Castiglione Olona. The first ideal city of Humanism (Castiglione Olona. La prima città ideale dell'Umanesimo), Milano, Mimesis, 2018 (in Italian).

[22] A. Spiriti, Nostra Signora di Loreto: the Imago Mariae in the reconstruction of Finalborgo (Nostra Signora di Loreto: l'Imago Mariae nella ricostruzione di Finalborgo), in: M. Caldera, G. Murialdo, M. Tassinari (eds.), The Del Carretto. Power and artistic commission of a noble dynasty between Liguria and Piedmont (XIVXVI century) (I Del Carretto. Potere e committenza artistica di una dinastia signorile fra Liguria e Piemonte (XIV-XVI secolo)), Milano, Scalpendi, 2020, pp. 153-159 (in Italian).

[23] R. Cecchini, G. Gaudini, S. Mammana, Pienza and the design of utopia (Pienza e il disegno dell'utopia), Verona, Gianni Bussinelli editore, 2020 (in Italian).

[24] F. Del Sole, Pienza, the European dream of Pope Pius II Piccolomini (Pienza, il sogno europeo di Papa Pio II Piccolomini), in: “ArcHistoR”, 7, 14, 2021, pp. 22-47 (in Italian).

[25] E.S. Piccolomini - Papa Pio II, The comments (I commentari), ed. L. Totaro, Milano, Adelphi, 1989 (in Italian).

[26] A. Pérez-Gómez, Filarete's Sforzinda: the Ideal City as a Poetic and Rhetorical Construction (Filarete's Sforzinda: the Ideal City as a Poetic and Rhetorical Construction), in "Chora", 7, 2016, pp. 243-262 (in Italian)

[27] J. Gritti, The squares of Sforzinda in the tenth book of the treatise of Filarete (and a note on the journey of Galeazzo Maria Sforza in the Ferrara area) (Le piazze di Sforzinda nel decimo libro del trattato di Filarete (e una nota sul viaggio di Galeazzo Maria Sforza nel ferrarese)), in: A. Ippoliti (ed.), Biagio Rossetti and his time (Biagio Rossetti e il suo tempo), proceedings of the international conference, Ferrara 2016, Roma, GBE/Ginevra Bentivoglio editoriA, 2018, pp. 193-204 (in Italian).

[28] R. Martufi, The hanging garden of the ducal palace of Urbino (Il giardino pensile del palazzo ducale di Urbino), in: A. Cerboni Baiardi (ed.), The Duke's gardens, places of delight from the Montefeltro to the Della Rovere (I giardini del duca, luoghi di delizia dai Montefeltro ai Della Rovere), Cinisello Balsamo, Silvana Editoriale, 2018, pp. 89-99 (in Italian).

[29] M. Ceriana, K. Christiansen (eds.), Fra Carnevale: a Renaissance artist from Filippo Lippi to Piero della Francesca (Fra Carnevale: un artista rinascimentale da Filippo Lippi a Piero della Francesca), exhibition catalogue, Milano, Olivares, 2004 (in Italian).

[30] A. G. De Marchi, Notes on Predella Colonna and Fra Carnevale (Note sulla Predella Colonna e su Fra Carnevale), in: "Bollettino d'arte", s. 7, $102,35-36,2017$, pp. 253-258 (in Italian).

[31] M. Bevilacqua, Giulianova: the construction of an "ideal city" of the Renaissance; theories, clients, construction sites (Giulianova: la costruzione di una "città ideale" del Rinascimento; teorie, committenti, cantieri), Napoli, Electa Napoli, 2002 (in Italian). 
[32] V. Galati, Temples with a central plan of the fifteenth century, as urban and territorial hubs in the commission of the Acquaviva d'Aragona: the temple of Santa Caterina in Conversano, from the commission of the Orsini and the Knights of Rhodes to the benefit of the Acquaviva; the foundation of San Flaviano in Giulianova between Leon Battista Alberti and Francesco di Giorgio Martini (Templi a pianta centrale del XV secolo, come fulcri urbani e territoriali nella committenza degli Acquaviva d'Aragona: il tempietto di Santa Caterina a Conversano, dalla committenza degli Orsini e dei Cavalieri di Rodi al beneficio degli Acquaviva; la fondazione di San Flaviano a Giulianova tra Leon Battista Alberti e Francesco di Giorgio Martini), in: "Annali di storia dell'urbanistica e del paesaggio", 2, 2014 (ed. 2015), pp. 39-66 (in Italian).

[33] S. Fatuzzo, The Pallavicino family in Cortemaggiore: history, architecture, documents (La famiglia Pallavicino a Cortemaggiore: storia, architettura, documenti), Padova, Università degli Studi di Padova, 2019 (in Italian).

[34] E. Svalduz, Under the sign of the prince: Baldassarre Peruzzi's model in the Cathedral of Carpi (Sotto il segno del principe: il modello di Baldassarre Peruzzi nel Duomo di Carpi), in: C. Togliani (ed.), A palace in the form of words. Essays in honor of Paolo Carpeggiani (Un palazzo in forma di parole. Scritti in onore di Paolo Carpeggiani), Milano FrancoAngeli, 2016, pp. 214-221 (in Italian).

[35] E. Svalduz, Not only Ferrara: "magistro Biaxio ingignero" in Carpi (1500-1505) (Non solo Ferrara: "magistro Biaxio ingignero" a Carpi (1500-1505)), in: A. Ippoliti (ed.), Biagio Rossetti and his time (Biagio Rossetti e il suo tempo), proceedings of the international conference, Ferrara 2016, Roma, GBE/Ginevra Bentivoglio editoriA, 2018, pp. 75-86 (in Italian).

[36] D. Friedman, Leonardo's plan of Imola (La pianta di Imola di Leonardo, 1502), in: M. Folin (ed.), Representing the city: urban topographies in Italy under the ancien regime (Rappresentare la città: topografie urbane nell'Italia di antico regime), Reggio Emilia, Diabasis, 2010, pp. 121-144 (in Italian).
[37] A. Marchesi, The urban redevelopment of the Herculean Addition of Ferrara according to an Este project of 1556 (La riqualificazione urbana dell'Addizione erculea di Ferrara secondo un progetto estense del 1556), in "Schifanoia", 58/59, 2020, pp. 99-108 (in Italian).

[38] Leonardo's places. Milan, Vigevano and France (I luoghi di Leonardo. Milano, Vigevano e la Francia), proceedings of the internazional congress, Vigevano 2014, Pisa, Felici Edizioni, 2017 (in Italian).

[39] Ferrandina and Montescaglioso: examples of historical-urbanistic research; debates and research (Ferrandina e Montescaglioso: esempi di ricerca storico-urbanistica; dibattiti e ricerche), Roma, Gangemi, 1994

[40] A. Ghisetti Giavarina, Renaissance foundations in the Kingdom of Naples: Giulianova, Ferrandina, Acaya (Fondazioni rinascimentali nel Regno di Napoli: Giulianova, Ferrandina, Acaya), in: A. Casamento (ed.), Urban foundations: new European cities from the Middle Ages to the twentieth century (Fondazioni urbane: città nuove europee dal Medioevo al Novecento), Roma, Kappa Edizioni, 2021, pp. 141-154 (in Italian).

[41] P. Leo, The fortified city of Acaya (1535): the ancient walls of Segine (La città fortificata di Acaya (1535): le antiche mura di Segine), Galatina, Congedo, 2011 (in Italian).

[42] J. Pieper (ed.), Sabbioneta: stately architecture of an ideal city of the Renaissance (Sabbioneta: herrschaftliche Architektur einer Idealstadt der Renaissance), Berlin, Geymüller, Verlag für Architektur, 2019 (in German).

[43] A. Spiriti, Pio IV Medici and the Castle of Melegnano (Pio IV Medici e il Castello di Melegnano), Cinisello Balsamo, Silvana Editoriale, 2021 (in Italian).

[44] A. Spiriti, Zenobia Del Carretto Doria: from the legacy of Finale to the ideal city of Loano (Zenobia Del Carretto Doria: dall'eredità del Finale alla città ideale di Loano), in Caldera, Murialdo, Tassinari (eds.), 2020, pp. 171-179 (in Italian).

[45] R. Cantarelli, Palmanova - form, space, architecture (Palmanova - forma, spazio, architettura), LetteraVentidue, Siracusa, 2019 (in Italian). 